\title{
One more look at guidelines for primary and secondary prevention of cardiovascular disease in women
}

Genovefa Kolovou' ${ }^{1}$ Apostolia Marvaki ${ }^{1}$, Helen Bilianou ${ }^{2}$

${ }^{1}$ Cardiology Department, Onassis Cardiac Surgery Center, Athens, Greece ${ }^{2}$ Cardiology Department, Tzanio Hospital, Piraeus, Greece

Submitted: 22 July 2010

Accepted: 27 September 2010

Arch Med Sci 2011; 7, 5: 747-755

DOI: $10.5114 /$ aoms.2011.25547

Copyright (c) 2011 Termedia \& Banach

\section{Abstract}

The most common cause of death in menopausal women is due to complications from cardiovascular disease. However, many physicians feel that the prevention in women may be delayed, because women present the clinical manifestations of cardiovascular disease 10 years later than men. Another matter emerged following the results of the Women's Health Initiative study and of the Heart Estrogen/Progestin Replacement Study. Thus the proper interpretation and implementation of science should be included in a strict procedure of appreciation and clear communication for both the qualitative and quantitative evaluation of evidence, used for the clinical guidelines. Based on objective scientific collaboration among various specialities, guidelines for the prevention of cardiovascular disease of adult women with a broad range of cardiovascular risk have been formed. In this review, the guidelines or recommendations which have been reported in the last 2 decades by various scientific societies for prevention of cardiovascular disease in women will be analysed.

Key words: women, coronary artery disease, premenopausal, postmenopausal, hormone replacement therapy.

\section{Introduction}

The most common cause of death in menopausal women is due to complications from cardiovascular (CV) disease and the most severe complication of CV disease is sudden death. In the Framingham Heart Study [1-4], it was found that $2 / 3$ of women who died suddenly had been asymptomatic before. No wonder that these circumstances lead medical societies to suggest more intensive primary and secondary prevention in women [5]. However, many physicians feel that the prevention in women can be delayed, because women present the clinical manifestations of CV disease 10 years later than men. Another matter emerged following the results of the Women's Health Initiative study [6, 7] and of the Heart Estrogen/Progestin Replacement Study (HERS) [7]. Both studies unexpectedly reported an association between combined hormone replacement therapy (HRT) and increased CV events [8-11]. This required a critical review and strategy based on documented evidence for prevention of CV disease in women. The proper interpretation and implementation of science with the aim of improving preventive care should be included in a strict procedure of appreciation and clear communication for both the qualitative and quantitative evaluation of evidence used for the clinical guidelines. Moreover, all existing evidence, including that for men, should be involved after modification for the

\author{
Corresponding author: \\ Genovefa D. Kolovou MD, \\ PhD, FESC, SFASA, FACS \\ Cardiology Department \\ Onassis Cardiac \\ Surgery Center \\ 356 Sygrou Ave 17674 \\ Athens, Greece \\ Phone: +30 2109493520 \\ Fax: +30 2109493336 \\ E-mail: \\ genovefa@kolovou.com
}


formulation of the guidelines for women. Additionally, many patients do not share a similar clinical profile to patients participating in clinical trials; thus the conclusions should be drawn regarding the potential similarities, and generalization from basic research to clinical practice.

Based on objective scientific collaboration among various specialities, guidelines for prevention of CV disease of adult women with a broad range of CV risk have been formed.

Also, after 2 decades of applying the most sophisticated techniques for the diagnosis of CV disease in its early stages, the classification as primary and secondary prevention has become less important. Instead, the grading of CV risk and identification of a high risk group have become more significant.

The guidelines do not represent obligatory rules, but aim at updating physicians' knowledge regarding the severe problem that every aging woman is going to face, and its prompt implementation. Below, the guidelines or suggestions which have been reported in the last 2 decades by various scientific societies for prevention of $\mathrm{CV}$ disease in women will be analysed.

\section{American Heart Association Scientific Statement 'Cardiovascular Disease in Women'}

In 1997 the American Heart Association (AHA) published 'Cardiovascular Disease in Women' [5]. In this statement the role of major risk factors (RFs), preceding CV disease, such as smoking, arterial hypertension (including isolated systolic hypertension), dyslipidaemia, diabetes mellitus, obesity, sedentary life style, and unhealthy diet, has been emphasized [5]. Smoking was considered to be the first reversible RF and responsible for $>50 \%$ of myocardial infarctions (MI) in middle aged women [12]. Moreover, it was emphasised that CV RFs which are manifested in women have different frequency and their reduction is often less intense than in men. For example, the rate of reduction of smoking is lower in women than in men. The incidence of obesity increases more often in aging women than in aging men. Also, more than $52 \%$ of women aged above 45 years old present an elevated blood pressure, and more than $40 \%$ of women aged above 55 years old present elevated blood cholesterol levels [5].

However, as far as primary prevention is concerned, pharmacotherapy has been recommended only for the high risk group of patients, and a change of lifestyle, such as cessation of smoking, regular physical activity, maintenance of a normal body weight, and consumption of a diet containing low unsaturated fatty acids and intake of increased amounts of fruits and vegetables, has been stressed.

Concerning secondary prevention after $\mathrm{MI}$, physicians should consult the guidelines, published in 1995 and 1996, for the management of patients with acute MI [13-16]. According to these guidelines the administration of $\beta$-blockers, inhibitors of angiotensin-converting enzyme (ACE) (when the left ventricular ejection fraction is $<40 \%$ ), aspirin and lipid-lowering drugs was recommended. The administration of calcium channel blockers, antiarrhythmic drugs, or magnesium, has not been recommended as a routine therapy during the occurrence of an MI or later.

Concerning secondary prevention after stroke, the guidelines have recommended only the administration of aspirin. Moreover, according to this statement, the administration of HRT in postmenopausal women has been recommended on an individualized basis.

\section{AHA/ACC Scientific Statement: Consensus Panel Statement}

The first guidelines regarding the prevention of cardiac disease in women were published in 1999 by the American Heart Association (AHA)/American College of Cardiology (ACC) Scientific Statement: Consensus Panel Statement $[17,18]$. Until then, the medical community had not paid great attention to RFs in women. In the HERS study [7], only $10 \%$ of participating women presented desirable low density lipoprotein (LDL) cholesterol levels, according to the guidelines of the National Cholesterol Education Program (NCEP) [19, 20]. Moreover, women had fewer possibilities to participate in a rehabilitation programme, after an MI, leading to less intensive treatment. However, in 1995 and 1997, the recommendations for primary and secondary prevention of coronary heart disease, which could be applied to women, were published (see above).

There is an exceptional aspect of women's RFs. This advantage of women had not been mentioned before in any guidelines. Pregnancy and the life period before pregnancy represent the most favourable period of a woman's life for reviewing the RFs and lifestyle, in order to limit the future CV morbidity. The cessation of smoking in pregnant women should be recommended to be continued also after the delivery. The prevention of excess increase of body weight during pregnancy may reduce the risk of occurrence of future events of CV disease. The prevention in women should be emphasized since it is essential, having in mind that CV disease in women increases with age.

In those guidelines, the administration of HRT in perimenopausal and postmenopausal women for the prevention of CV disease, osteoporosis, or possible dementia was also a decision that physicians should make. In particular, physicians should consider the potential favourable effects of HRT and underlying complications of these drugs, including breast cancer, uterus cancer, thromboembolic episodes and diseases of the gallbladder.

Furthermore, the guidelines emphasized that the regulation of RFs preceding CV disease, such as diabetes mellitus and other RFs (abnormal lipid profile 
and/or arterial hypertension), plays an essential role in reducing CV events. For example, low plasma high density lipoprotein (HDL) cholesterol level in women aged $>65$ years is considered to be more important for the prediction of CV disease than in men at the same age [21]. At that time, the guidelines of the NCEP (ATP II, 1994) [22] stressed the imperative need for more aggressive management of low HDL cholesterol and elevated triglyceride levels in women. In the same guidelines, a recommendation for administration of HRT to postmenopausal women for the regulation of increased LDL cholesterol was introduced [22]. If LDL cholesterol levels remained elevated, a recommendation for administration of a lipid-lowering drug, and in particular statin (inhibitors of HMG CoA reductase), was introduced. Nowadays, this recommendation has been modified (see below), and administration of statins in postmenopausal women represents a first line choice, with the same favourable results as in men.

\section{Evidence-Based Guidelines for Cardiovascular Disease Prevention in Women}

In 2004, the guidelines (Evidence-Based Guidelines for Cardiovascular Disease Prevention in Women) were published by the Experts Committee, with Mosca being the first author [23, 24]. A great effort has been made in order to create evidence-based guidelines. In these guidelines, women were classified in groups, depending on risk level (high, moderate, low, and favourable). As a high risk group (Framingham global risk (10-year (V risk) > 20\%) were classified women who have been diagnosed with coronary heart disease, stroke, peripheral artery disease, abdominal aortic aneurysm, diabetes mellitus or chronic renal failure. As a moderate risk group (Framingham global risk 10-20\%) were classified women with subclinical CV disease (coronary artery calcification) or metabolic syndrome or multiple RFs or one significantly elevated RF, or who have $1^{\text {st }}$ degree relatives with early CV disease $(<55$ years in men and $<65$ years in women). As a low risk group (Framingham global risk $<10 \%$ ) were classified women who have only one or no RF, while women with optimal levels of RFs and heart healthy lifestyle should be characterised as a favourable risk group (Framingham global risk < 10\%).

Also, it should be noted that the Expert Committee has classified for the first time the clinical recommendations, depending on evidence. Evidence was classified (Table I) according to the type of study and its primary endpoints (death, MI, stroke, revascularization procedures (angioplasty or aortocoronary bypass) and heart failure or some combination of them). Finally, the Expert Committee formulated the clinical guidelines for women (Tables II and III) [23, 24].
The diet recommended by the Experts Committee concerned healthy nutrition. The Experts Committee has concluded that the consumption of fish is correlated with the reduction of risk for CV disease. However, women of reproductive age, and particularly pregnant women, should avoid the consumption of fish such as shark, swordfish, chub mackerel, common mackerel, and finally, white cod, because those fish contain high amounts of mercury, and may affect the normal growth of the nervous system of the fetus. Pregnant women are allowed to consume fish such as salmon and sole.

For the management of classical RFs, the Experts Committee has referred physicians to the guidelines of Scientific Associations, respectively the National Cholesterol Education Program Adult Treatment Panel III [19], the Seventh Report of the Joint National Committee on Prevention, Detection, Evaluation and Treatment of High Blood Pressure [25], and the American Diabetes Association [26].

Concerning the treatment of high blood pressure, in hypertensive patients, women and men, lowering blood pressure causes a significant reduction of $\mathrm{CV}$ events. Treatment with thiazide diuretics is recommended as a first line therapy while $\beta$-blockers are not prescribed now as a common antihypertensive therapy in patients with no complications [25].

Table I. Classification of evidence levels [23, 24]

\begin{tabular}{|ll|}
\hline Classification & Strength of recommendation \\
\hline Class & Intervention is useful and effective \\
\hline IIb & $\begin{array}{l}\text { Evidence is in favour of usefulness } \\
\text { and efficacy }\end{array}$ \\
\hline III & $\begin{array}{l}\text { Usefulness and efficacy are less } \\
\text { established }\end{array}$ \\
\hline Level of evidence & Intervention is not useful and may be \\
\hline harmful
\end{tabular}


Table II. Clinical recommendations, for Ifestyle and major RFs intervention, in women [23, 24]

\begin{tabular}{|c|c|}
\hline Clinical recommendations & $\begin{array}{l}\text { Class, level, } \\
\text { generalizability } \\
\quad \text { index }\end{array}$ \\
\hline \multicolumn{2}{|l|}{ Lifestyle interventions } \\
\hline Cigarette smoking: consistently encourage women to avoid smoking, active or passive & I, B, 1 \\
\hline $\begin{array}{l}\text { Physical activity: consistently encourage women to perform exercise of moderate intensity, } \\
\text { for } 30 \text { min (brisk walking), on most days of the week, preferably on all days of the week }\end{array}$ & I, B, 1 \\
\hline $\begin{array}{l}\text { Cardiac rehabilitation: women, after an acute coronary event, or an intervention in coronary arteries, } \\
\text { or with chronic angina pectoris, should participate in a comprehensive risk reduction regimen such } \\
\text { as cardiac rehabilitation programme, or should implement the instructions of the physician at home, } \\
\text { or should participate in a community programme }\end{array}$ & I, B, 2 \\
\hline $\begin{array}{l}\text { Heart healthy diet: constant encouragement to follow a healthy diet, e.g. consumption of a variety } \\
\text { of fruits, vegetables, cereals, dairy products with low or without fat, consumption of fish, legumes, } \\
\text { and proteins with low content of unsaturated fat (poultry, lean meat, plant). Restriction of consumption } \\
\text { of unsaturated fat ( }<10 \% \text { of total calories), cholesterol ( } 300 \mathrm{mg} / \text { daily), and trans-fatty acids }\end{array}$ & I, B, 1 \\
\hline $\begin{array}{l}\text { Weight maintenance or reduction: constant encouragement of maintenance of body weight or } \\
\text { reduction, a proper balance between physical activity and caloric uptake, and, if necessary, } \\
\text { implementation of a regular programme, for a body weight index of } 18.5 \mathrm{~kg} / \mathrm{m}^{2} \text { to } 24.9 \mathrm{~kg} / \mathrm{m}^{2} \\
\text { and a waist circumference }<88 \mathrm{~cm} \text { to be maintained/accomplished }\end{array}$ & I, B, 1 \\
\hline $\begin{array}{l}\text { Psychosocial factors: women with CV disease should be evaluated for potential depression, } \\
\text { and should be reported or cured when there are indications }\end{array}$ & Ila, B, 2 \\
\hline $\begin{array}{l}\Omega-3 \text { fatty acids: these substances may be administered in high risk women, in the form of diet } \\
\text { supplements }\end{array}$ & Ilb, B, 2 \\
\hline $\begin{array}{l}\text { Folic acid: it may be administered in high risk women, as a diet supplement, if homocysteine levels } \\
\text { are high }\end{array}$ & Ilb, B, 2 \\
\hline \multicolumn{2}{|l|}{ Major RF intervention } \\
\hline $\begin{array}{l}\text { Arterial hypertension - lifestyle: encouragement to maintain a favourable blood pressure level } \\
\text { of }<120 / 80 \mathrm{mmHg} \text {, during all lifetime }\end{array}$ & I, B, 1 \\
\hline $\begin{array}{l}\text { Arterial pressure - drugs: pharmacotherapy is indicated when arterial pressure is }>140 / 90 \mathrm{mmHg} \text {, } \\
\text { or lower, in combination with damage of target organ, influenced by hypertension. Thiazide diuretics } \\
\text { should be one of the drugs if there are no contraindications }\end{array}$ & I, A, 1 \\
\hline $\begin{array}{l}\text { Lipids, lipoproteins: women's favourable levels are }<100 \mathrm{mg} / \mathrm{dl} \text { for } \mathrm{LDL} \text { cholesterol, }>50 \mathrm{mg} / \mathrm{dl} \\
\text { for HDL cholesterol, }<150 \mathrm{mg} / \mathrm{dl} \text { for triglycerides, and }<130 \mathrm{mg} / \mathrm{dl} \text { for non-HDL cholesterol } \\
\text { (total cholesterol - HDL cholesterol). Lifestyle change should be encouraged }\end{array}$ & I, B, 1 \\
\hline $\begin{array}{l}\text { Lipids - dietary therapy: consumption of saturated fat should be reduced to }<7 \% \text { of total calories, } \\
\text { and cholesterol to } 200 \mathrm{mg} \text { daily, in high risk women, or with elevated plasma LDL cholesterol levels. } \\
\text { Consumption of trans-fat should also be reduced }\end{array}$ & I, B, 1 \\
\hline $\begin{array}{l}\text { Lipids - pharmacotherapy - high risk: initiation of LDL lowering treatment (statins preferred), } \\
\text { along with lifestyle change, in high risk women, and } L D L \text { cholesterol } \geq 100 \mathrm{mg} / \mathrm{dl} \text {. }\end{array}$ & I, A, 1 \\
\hline $\begin{array}{l}\text { Initiation of treatment with statins for LDL lowering in high-risk women, and LDL cholesterol } \\
<100 \mathrm{mg} / \mathrm{dl} \text {, unless contraindicated. Initiation of treatment with nicotinic acid or fibrates when }\end{array}$ & I, B, 1 \\
\hline $\mathrm{HDL}$ cholesterol is low or non-HDL cholesterol is elevated & I, B, 1 \\
\hline $\begin{array}{l}\text { Lipids - pharmacotherapy - moderate risk: ilnitiation of LDL lowering treatment (statins preferred), } \\
\text { along with lifestyle change, when LDL cholesterol is } \geq 130 \mathrm{mg} / \mathrm{dl} \text {. Nicotinic acid or fibrates when }\end{array}$ & I, A, 1 \\
\hline $\begin{array}{l}\mathrm{HDL} \text { cholesterol is low, or non-HDL cholesterol is high, after the target LDL cholesterol level has been } \\
\text { accomplished }\end{array}$ & I, B, 1 \\
\hline $\begin{array}{l}\text { Lipids - pharmacotherapy - low risk: initiation of LDL lowering treatment in women with 0-1 RFs } \\
\text { and } L D L \text { cholesterol } \geq 190 \mathrm{mg} / \mathrm{dl} \text {, or multiple RFs and } L D L \text { cholesterol } \geq 160 \mathrm{mg} / \mathrm{dl} \text {. Nicotinic acid }\end{array}$ & Ila, B \\
\hline $\begin{array}{l}\text { or fibrates when HDL cholesterol is low, or non-HDL cholesterol is high, after the target } \\
\text { LDL cholesterol level has been accomplished }\end{array}$ & Ila, B, 1 \\
\hline $\begin{array}{l}\text { Diabetes mellitus: lifestyle change and pharmacotherapy for } \mathrm{HbA}_{1 \mathrm{c}} \text { level (haemoglobulin adult } 1 \mathrm{c} \text { ) } \\
<7 \% \text { to be accomplished }\end{array}$ & I, B, 1 \\
\hline
\end{tabular}


Table III. Clinical recommendations for drug interventions, in women [23, 24]

\begin{tabular}{|lc|}
\hline Recommendations & $\begin{array}{c}\text { Class, level, } \\
\text { generalizability } \\
\text { index }\end{array}$ \\
\hline $\begin{array}{l}\text { Aspirin - high risk: administration of aspirin (75-162 mg daily) or clopidogrel, } \\
\text { if there is a contraindication for aspirin, in high-risk women, unless contraindicated }\end{array}$ & I, A, 1 \\
\hline $\begin{array}{l}\text { Aspirin-moderate risk: administration of aspirin (75-162 mg daily) in moderate risk women, } \\
\text { provided that blood pressure has been adequately controlled, and its favourable effect exceeds } \\
\text { the probability of bleeding from the gastrointestinal system }\end{array}$ & Ila, B, 2 \\
\hline $\begin{array}{l}\beta \text {-Blockers: these drugs should be administered indefinitely in all women with a history of myocardial } \\
\text { infarction, or with chronic myocardial ischaemia, unless contraindicated }\end{array}$ & I, A, 1 \\
\hline $\begin{array}{ll}\text { ACE inhibitors: these drugs should be administered in high risk women, unless contraindicated } \\
\text { Angiotensin II receptor (AT } \text { ) inhibitors: these drugs should be administered in high risk women } \\
\text { with clinically confirmed heart failure, or an ejection fraction of < 40\%, who cannot tolerate ACE inhibitors }\end{array}$ & I, B, 1 \\
\hline
\end{tabular}

In addition, the Experts Committee has formed guidelines for the prevention of stroke in women who developed chronic or paroxysmal atrial fibrillation (Table IV).

The Experts Committee has also established the priority in prevention of CV disease in women, depending on risk group classification. In the high risk group (risk < 20\%), the following have been proposed as class I recommendations: smoking cessation, physical activity or cardiac rehabilitation, dietary treatment, maintenance or reduction of body weight when necessary, arterial pressure control, lipid control or statin therapy, aspirin therapy, $\beta$-blocker therapy, ACE inhibitor therapy ( $A T_{1}$ inhibitors when $A C E$ inhibitors are contraindicated) and diabetes control. Also recommended in the same group are the evaluation or treatment of depression and the administration of $\Omega-3$ fatty acids and folic acid as class Ila and class IIb respectively. A class I recommendation dictates that the moderate risk women group (risk $10-20 \%$ ) should stop smoking, should be familiar with physical activity or cardiac rehabilitation, and maintain body weight or reduce it when necessary. In addition, the same group should be encouraged to follow dietary treatment and treatment of every RF according to the guidelines, whereas according to the class Ila recommendation, these women are advised to follow an aspirin therapy regimen. Moreover, in the low risk group (risk < 10\%), smoking cessation, physical activity or cardiac rehabilitation, dietary treatment, maintenance or reduction of body weight and the proper regulation of every RF for heart disease are rated as class I recommendations. Finally, concerning stroke prevention in women with atrial fibrillation, in the high or moderate risk group it was recommended to receive treatment with coumarin, whereas the low risk group $(<1 \%)$ or women with contraindications for administration of coumarin regimen should be treated with aspirin according to a class I recommendation.

For the first time these guidelines clarified if patients should be prescribed HRT. Based on recent studies, HRT has been recommended as class III, level A. This conservative management of postmenopausal women is recommended, until new data from clinical studies would emerge. The Experts Committee concluded that administration of hormone replacement for the amelioration of symptoms or for osteoporosis concerns other scientific organizations.

\section{Recommendations from the U.S. Preventive Services Task Force (USPSTF)}

In 2005 the recommendations from the U.S. Preventive Services Task Force (USPSTF) were published [27]. The USPSTF categorized its recommendations according to one of five classifications depending on level of evidence. If the USPSTF strongly recommends physicians to provide the recommendations to eligible patients and has found enough evidence, proving the benefits, then this recommendation is classified as class A. When the USPSTF

Table IV. Prevention of stroke in women with atrial fibrillation [23, 24]

\begin{tabular}{|lc|}
\hline Guidelines & $\begin{array}{c}\text { Class, level, } \\
\text { generalizability } \\
\text { index }\end{array}$ \\
\hline $\begin{array}{l}\text { Coumarin - atrial fibrillation: in women with chronic or paroxysmal atrial fibrillation, } \\
\text { coumarin should be administered, for INR to be maintained at a level of 2.0-3.0, unless the risk } \\
\text { for a stroke is }<1 \% \text {, or there is a high risk of bleeding }\end{array}$ & I, A, 1 \\
\hline $\begin{array}{l}\text { Aspirin - atrial fibrillation: in women with chronic or paroxysmal atrial fibrillation, } \\
\text { aspirin can be administered, in a dose of } 325 \mathrm{mg} / \text { daily, if there is a contraindication for administration } \\
\text { of coumarin, or the risk of a stroke is }<1 \%\end{array}$ & $\mathrm{I}, \mathrm{A}, 1$ \\
\hline
\end{tabular}


recommends physicians to provide the recommendations to eligible patients and has found enough evidence, proving that benefits exceed complications, the recommendation is categorised as class $B$. The class $C$ recommendation means that the USPSTF has found evidence proving that the benefits just counterbalance the complications and makes no recommendation for or against the implementation of guidelines, while when the USPSTF recommends against routine implementation of guidelines and has found enough evidence proving that it is not effective and the complications exceed the benefits, the recommendation should be characterized as class D. Finally, the class E recommendation shows that the USPSTF does not recommend the implementation of guidelines, because there is no evidence concerning either benefits or complications. In these guidelines the main points regarded the administration of HRT in postmenopausal women [27]. The USPSTF concluded that administration of a combination consisting of oestrogens and progesterone for management of chronic diseases in postmenopausal women should not be advised in everyday practice, as also was stated in Evidence Based Guidelines for Cardiovascular Disease Prevention in Women. The administration of HRT has been classified as Class D. The USPSTF has found quite enough evidence proving that HRT has not been effective, and potential complications exceed the possible benefits.

The combination of oestrogens with progesterone has beneficial effects on reduction of fractures [28] and intestine cancers $[29,30]$, but has no effect, or even increases, the CV, thromboembolic [31, 32] and cholecystitis events [8,33], elevates the risk of occurrence of breast cancer [34-37], strokes [38] and dementia [39], and finally reduces cognitive functions [40]. The USPSTF has reported that postmenopausal women present a possibility of having coronary heart disease (46\%), stroke (20\%), hip fractures (15\%), breast cancer (10\%), and uterus cancer (2.6\%) [27].

\section{Cardiovascular Diseases in Women: a Statement from the Policy Conference of the European Society of Cardiology}

The European Society of Cardiology in 2006 initiated the extensive programme "Women at Heart", aiming to coordinate the research and further education for the prevention of CV disease in women and particularly of coronary heart disease and strokes [41]. The first stage of this programme was to establish a regular conference for recording various issues. A lot of topics have been discussed, and some of them will be analysed below.

In 2004, the World Health Organization published an estimation that in Europe, CV disease is responsible for $43 \%$ of deaths in men and $55 \%$ in women [41]. Coronary heart disease is responsible for $21 \%$ of deaths in men and for $23 \%$ in women, while stroke is responsible for $11 \%$ of deaths in men and
$18 \%$ in women. However, women have not realized this risk [23] and still believe that breast cancer causes more deaths.

Another topic which has been discussed th this conference concerns the difference in response to therapy between the two genders. For example, aspirin administration reduces mortality from stroke, and yet does not affect the mortality caused by $\mathrm{MI}$ (in contrast to what happens in men) [42].

During this conference the tables evaluating the probability of death in the next 10 years (SCOPE charts) were created. Also, HRT in postmenopausal women (not recommended for the prevention of CV disease), the difference that exists concerning the manifestation and management of coronary heart disease between the two genders, the risk and therapy of stroke in women with atrial fibrillation, and finally the cost-benefit ratio, were analysed [41].

\section{Evidence-Based Guidelines for Cardiovascular Disease Prevention in Women (Updated)}

In 2007, the updated clinical guidelines for the prevention of $\mathrm{CV}$ disease in women were published (Tables $V$ and $\mathrm{VI}$ ) [43, 44]. Below, only the differences between the previous guidelines will be analysed.

The classification of women, depending on risk level, has been partially modified in comparison with the Evidence-Based Guidelines for Cardiovascular Disease Prevention in Women. Women with documented coronary heart disease, stroke, peripheral artery disease, abdominal aortic aneurysm, end stage renal disease, diabetes mellitus or Framingham 10 -year global risk > 20\% are classified as a high risk group. In addition, women with one or more than one major RF for CV disease, such as smoking, unhealthy diet, physical inactivity, obesity and specifically central obesity, arterial hypertension, metabolic syndrome, dyslipidaemia and family history with an early CV disease ( $<55$ years in men, and $<65$ years in women) are categorized in the moderate risk group. Also, women who present reduced tolerance in exercise stress testing and/or abnormal heart rate after the test or evidence of subclinical CV disease according to coronary artery calcification belong to the moderate risk group. Finally, women who have a healthy lifestyle, no RF or Framingham 10-year global risk $>20 \%$ should be classified in the favourable risk group.

Emphasis has been paid to the total risk (of the whole lifetime) and not only to the next 10 years, which is determined by the Framingham algorithm.

Aspirin administration for the prevention of $\mathrm{CV}$ disease in women aged $>65$ years, or for the prevention of stroke in women aged $<65$ years, is cited in Table V.

\section{Conclusions}

The CV diseases, in spite of the significant interventions that have been made for primary and 
Table V. Clinical guidelines for women [43, 44]

\begin{tabular}{|c|c|}
\hline Management & Class, level \\
\hline \multicolumn{2}{|l|}{ Aspirin - high risk } \\
\hline Administration of aspirin $(75-365 \mathrm{mg})$ if no contraindications & I, A \\
\hline When there is intolerance to aspirin in high risk women, clopidogrel would be administered & I, B \\
\hline $\begin{array}{l}\text { Aspirin - other risks or healthy women } \\
\text { In women aged } \geq 65 \text { years, aspirin administration ( } 81 \text { or } 100 \mathrm{mg} \text { every other day), provided there is } \\
\text { adequate control of arterial pressure, and as long as the favourable effects on prevention of } \mathrm{Ml} \\
\text { or stroke exceed the potential of a haemorrhage from the gastrointestinal system and cerebral arteries }\end{array}$ & $\mathrm{IIb}, \mathrm{B}$ \\
\hline $\begin{array}{l}\beta \text {-Blockers } \\
\beta \text {-Blockers should be indefinitely administered in all women with a history of MI, or with myocardial } \\
\text { dysfunction, with or without symptoms of cardiac failure, if there are no contraindications }\end{array}$ & I, A \\
\hline $\begin{array}{l}\text { ACE inhibitors } / \mathrm{AT}_{1} \text { inhibitors } \\
\text { The ACE inhibitors should be administered if there are no contraindications, in women with an } \mathrm{MI} \\
\text { and clinical manifestations of heart failure, or with an ejection fraction } \leq 40 \% \text {, or with diabetes mellitus } \\
\text { In women with } \mathrm{MI} \text { and clinical manifestations of heart failure, or with an ejection fraction } \leq 40 \% \text {, } \\
\text { or with diabetes mellitus and intolerance to ACE inhibitors, angiotensin II, } \mathrm{AT}_{1} \text { receptors antagonists } \\
\text { should be administered }\end{array}$ & I, A \\
\hline $\begin{array}{l}\text { Aldosterone antagonists } \\
\text { These drugs should be administered after an MI, provided there is no severe renal insufficiency, } \\
\text { or hyperkalaemia, and if ACE inhibitors, } \beta \text {-blockers are received, an ejection fraction } \leq 40 \% \text {, } \\
\text { and symptoms of heart failure are presented }\end{array}$ & I, B \\
\hline
\end{tabular}

Table VI. Management of class III for the prevention of CV disease and MI in women [43, 44]

\begin{tabular}{|lc|}
\hline Management & Class, level \\
\hline $\begin{array}{l}\text { Treatment of menopause } \\
\text { The HRT for selective control of ER receptors (SERMs) should not be administered for either primary }\end{array}$ & III, A \\
or secondary prevention of CV disease & \\
\hline $\begin{array}{l}\text { Antioxidative supplements } \\
\text { Antioxidative vitamin supplements (vitamin E, C, } \beta \text {-carotene) should not be administered for primary }\end{array}$ & III, A \\
or secondary prevention of CV disease & \\
\hline $\begin{array}{l}\text { Folic acid } \\
\text { Folic acid, with or without supplements of vitamins } \mathrm{B}_{6} \text { or } \mathrm{B}_{12} \text {, should not be administered for primary } \\
\text { or secondary prevention of CV disease }\end{array}$ & III, A \\
\hline $\begin{array}{l}\text { Aspirin for the prevention of } \mathrm{Ml} \text { in women aged }<65 \text { years } \\
\text { Daily administration of aspirin in women aged }<65 \text { years old should not be recommended }\end{array}$ & III, B \\
for prevention of myocardial infarction. & \\
\hline
\end{tabular}

secondary preventions, are still the main cause of death in men and women of the western world $[18,45]$. Particularly, concerning women, deaths from $\mathrm{CV}$ disease, in every age group, are more prevalent and even higher than breast cancer [46]. Furthermore, in women, when the CV disease is revealed, the prognosis is more threatening compared to men. In the guidelines of the American Heart Association (AHA Scientific Statement, Evidence-Based Guidelines for Cardiovascular Disease Prevention in Women, see above), Mosca et al. [23] reported that in the United States of America, more than half a million of women were dying from CV disease each year. The World Health Organization (WHO) reported that women's deaths due to MI or stroke had a linear relationship with age.

The prevalence of $\mathrm{MI}$ in women with normal levels of oestrogens is very low ( $1 \%$ to $7 \%$ per 100000$)$ and
3-5 times lower than in men. Some studies suggested genetic variability [47]. However, this favourable relationship disappears in older women (> 65 years). The major determinant differentiating women from men is oestrogens. Oestrogens exert various actions on the organs of the human body, and particularly on the female body [48-51]. Their levels vary during the woman's life time and influence many organs.

The results from the clinical trials, reported by many investigators, regarding the hormone status of women and the occurrence of CV events have led to the conclusions that oestrogens exert a protective effect on atherogenesis, on the formation of atherosclerotic plaque, and subsequently on clinical manifestation of atherogenesis, namely CV disease. During the past years, the management of women has detained several scientific organizations, which have published 
guidelines. These guidelines are practical and helpful for physicians for the primary and secondary prevention of CV disease in women of all ages.

Observational studies reported that HRT was effective for most symptoms and diseases (particularly CV and osteoporotic disease) of menopausal women, and its use was recommended. However, disadvantages of HRT emerged from two large randomised controlled trials, HERS [7] and WHI [6], that found no benefits for prevention of CV diseases. Particularly, the WHI trial found an increase in breast cancer incidence and in CV events in healthy women. Later, the Million Women Study [52] showed an increase in breast cancer incidence associated with HRT. The publication of these findings led to different interpretations, among researchers, specialists (mainly gynaecologists and oncologists) and general practitioners, of HRT's benefits. Nowadays the use of HRT is limited to women in the early menopause and suffering from hard-to-bear symptoms. The HRT should be used for the shortest possible period and at the lowest effective doses. However, the results from the Kronos Early Estrogen Prevention Study (KEEPS) [53] and the Early versus Late Intervention Trial with Estradiol (ELITE) [53] are expected. Until then, HRT has been graded as a class III recommendation for the prevention of $\mathrm{CV}$ disease in women.

More research is required to evaluate the longterm benefits and side effects of HRT. However, there are a few new beliefs, for example that by starting HRT near menopause, the side effects may be diminished (the majority of studies evaluating the effects of HRT include women roughly 10 years after menopause). Another significant observation was drawn from the Women's Health in the Lund Area Study (3 600 postmenopausal women without HRT and 2816 postmenopausal treated with HRT or who were under HRT in the past) [54]. In this study, women who were receiving HRT had fewer risk factors for CV disease and followed a healthier lifestyle. Also, transdermal vaginal preparations may reduce certain adverse effects (breast, uterus and bowel cancer, pulmonary embolism) [55]. Additionally, low doses and very low doses of hormones may be more appropriate, especially in older women [56]. Until then, HRT should be decided by the physician separately for each woman based on symptoms, health status, personal beliefs and expectations. The individual riskbenefit balance is very important.

\section{References}

1. Fox CS, Evans JC, Larson MG, Kannel WB, Levy D. Temporal trends in coronary heart disease mortality and sudden cardiac death from 1950 to 1999: the Framingham Heart Study. Circulation 2004; 110: 522-7.

2. Kannel WB, Wilson PW, D'Agostino RB, Cobb J. Sudden coronary death in women. Am Heart J 1998; 136: 205-12.

3. Haider AW, Larson MG, Benjamin EJ, Levy D. Increased left ventricular mass and hypertrophy are associated with increased risk for sudden death. J Am Coll Cardiol 1998; 32: 1454-9.

4. Cupples LA, Gagnon DR, Kannel WB. Long- and short-term risk of sudden coronary death. Circulation 1992; 85: 11-8.

5. Mosca L, Manson JE, Sutherland SE, Langer RD, Manolio T, Barrett-Connor E. Cardiovascular disease in women: a statement for healthcare professionals from the American Heart Association. Writing Group. Circulation 1997; 96: 2468-82.

6. Rossouw JE, Anderson GL, Prentice RL, et al. Risks and benefits of estrogen plus progestin in healthy postmenopausal women: principal results from the Women's Health Initiative randomized controlled trial. JAMA 2002; 288: 321-33.

7. Speroff $L$. The heart and estrogen/progestin replacement study (HERS). Maturitas 1998; 31: 9-14.

8. Seelig MS, Altura BM, Altura BT. Benefits and risks of sex hormone replacement in postmenopausal women. J Am Coll Nutr 2004; 23: 482S-96S.

9. Alexandersen P, Karsdal MA, Christiansen C. Long-term prevention with hormone-replacement therapy after the menopause: which women should be targeted? Womens Health (Lond Engl) 2009; 5: 637-47.

10. Heiss G, Wallace R, Anderson GL, et al. Health risks and benefits 3 years after stopping randomized treatment with estrogen and progestin. JAMA 2008; 299: 1036-45.

11. Rosano GM, Vitale C, Silvestri A, Fini M. Hormone replacement therapy and cardioprotection: the end of the tale? Ann N Y Acad Sci 2003; 997: 351-7.

12. Willett WC, Green A, Stampfer MJ, et al. Relative and absolute excess risks of coronary heart disease among women who smoke cigarettes. N Engl J Med 1987; 317: 1303-9.

13. Fallen EL, Cairns J, Dafoe W, et al. Management of the postmyocardial infarction patient: a consensus reportrevision of 1991 CCS guidelines. Can J Cardiol 1995; 11: 477-86.

14. Kennedy JW. American Heart Association consensus panel statement on preventing heart attack and death in patients with coronary disease. J Am Coll Cardiol 1995; 26: 291.

15. Ryan TJ, Anderson JL, Antman EM, et al. ACC/AHA guidelines for the management of patients with acute myocardial infarction. A report of the American College of Cardiology/American Heart Association Task Force on Practice Guidelines (Committee on Management of Acute Myocardial Infarction). J Am Coll Cardiol 1996; 28: 1328-428.

16. Ryan TJ, Anderson JL, Antman EM, et al. ACC/AHA guidelines for the management of patients with acute myocardial infarction: executive summary. A report of the American College of Cardiology/American Heart Association Task Force on Practice Guidelines (Committee on Management of Acute Myocardial Infarction). Circulation 1996; 94: 2341-50.

17. Mosca L, Grundy SM, Judelson D, et al. Guide to Preventive Cardiology for Women. AHA/ACC Scientific Statement Consensus panel statement. Circulation 1999; 99: 2480-4.

18. Mosca L, Grundy SM, Judelson D, et al. AHA/ACC scientific statement: consensus panel statement. Guide to preventive cardiology for women. American Heart Association/American College of Cardiology. J Am Coll Cardiol 1999; 33: 1751-5.

19. Executive Summary of The Third Report of The National Cholesterol Education Program (NCEP) Expert Panel on Detection, Evaluation, And Treatment of High Blood 
Cholesterol In Adults (Adult Treatment Panel III). JAMA 2001; 285: 2486-97.

20. Grundy SM, Cleeman JI, Merz CN, et al. Implications of recent clinical trials for the National Cholesterol Education Program Adult Treatment Panel III Guidelines. Circulation 2004; 110: 227-39.

21. Manolio TA, Pearson TA, Wenger NK, Barrett-Connor E, Payne GH, Harlan WR. Cholesterol and heart disease in older persons and women. Review of an NHLBI workshop. Ann Epidemiol 1992; 2: 161-76.

22. National Cholesterol Education Program. Second Report of the Expert Panel on Detection, Evaluation, and Treatment of High Blood Cholesterol in Adults (Adult Treatment Panel II). Circulation 1994; 89: 1333-445.

23. Mosca L, Appel LJ, Benjamin EJ, et al. Evidence-based guidelines for cardiovascular disease prevention in women. American Heart Association scientific statement. Arterioscler Thromb Vasc Biol 2004; 24: e29-50.

24. Mosca L, Appel LJ, Benjamin EJ, et al. Summary of the American Heart Association's evidence-based guidelines for cardiovascular disease prevention in women. Arterioscler Thromb Vasc Biol 2004; 24: 394-6.

25. Cushman WC. JNC-7 guidelines: are they still relevant? Curr Hypertens Rep 2007; 9: 380-6.

26. American Diabetes Association Clinical Practice Recommendations 2001. Diabetes Care 2001; 24 Suppl 1: S1-133.

27. Hormone therapy for the prevention of chronic conditions in postmenopausal women: recommendations from the U.S. Preventive Services Task Force. Ann Intern Med 2005; 142: 855-60.

28. MacLean C, Newberry S, Maglione M, et al. Systematic review: comparative effectiveness of treatments to prevent fractures in men and women with low bone density or osteoporosis. Ann Intern Med 2008; 148 : 197-213.

29. Giroux V, Lemay F, Bernatchez G, Robitaille Y, Carrier JC. Estrogen receptor beta deficiency enhances small intestinal tumorigenesis in ApcMin/+ mice. Int J Cancer 2008; 123: 303-11.

30. Weige CC, Allred KF, Allred CD. Estradiol alters cell growth in nonmalignant colonocytes and reduces the formation of preneoplastic lesions in the colon. Cancer Res 2009; 69: 9118-24.

31. Rachon D, Teede H. Postmenopausal hormone therapy and the risk of venous thromboembolism. Climacteric 2008; 11: 273-9.

32. Gomes MP, Deitcher SR. Risk of venous thromboembolic disease associated with hormonal contraceptives and hormone replacement therapy: a clinical review. Arch Intern Med 2004; 164: 1965-76.

33. Lee JR. Thromboembolic events secondary to estrogen therapy. Am Fam Physician 1998; 57: 2071.

34. Shah NR, Borenstein J, Dubois RW. Postmenopausal hormone therapy and breast cancer: a systematic review and meta-analysis. Menopause 2005; 12: 668-78.

35. Pesch B, Ko Y, Brauch $\mathrm{H}$, et al. Factors modifying the association between hormone-replacement therapy and breast cancer risk. Eur J Epidemiol 2005; 20: 699-711.

36. Collins JA, Blake JM, Crosignani PG. Breast cancer risk with postmenopausal hormonal treatment. Hum Reprod Update 2005; 11: 545-60.

37. Norman RJ, MacLennan AH. Current status of hormone therapy and breast cancer. Hum Reprod Update 2005; 11: 541-3.

38. Bath PM, Gray LJ. Association between hormone replacement therapy and subsequent stroke: a metaanalysis. BMJ 2005; 330: 342.
39. Almeida OP, Flicker L. Association between hormone replacement therapy and dementia: is it time to forget? Int Psychogeriatr 2005; 17: 155-64.

40. Sherwin BB. Estrogen and cognitive functioning in women. Endocr Rev 2003; 24: 133-51.

41. Stramba-Badiale M, Fox KM, Priori SG, et al. Cardiovascular diseases in women: a statement from the policy conference of the European Society of Cardiology. Eur Heart J 2006; 27: 994-1005.

42. Ridker PM, Cook NR, Lee IM, et al. A randomized trial of low-dose aspirin in the primary prevention of cardiovascular disease in women. N Engl J Med 2005; 352: 1293-304.

43. Mosca L, Banka CL, Benjamin EJ, et al. Evidence-based guidelines for cardiovascular disease prevention in women: 2007 update. J Am Coll Cardiol 2007; 49: $1230-50$.

44. Mosca L, Banka CL, Benjamin EJ, et al. Evidence-based guidelines for cardiovascular disease prevention in women: 2007 update. Circulation 2007; 115: 1481-501.

45. Shaw LJ, Bugiardini R, Merz CN. Women and ischemic heart disease: evolving knowledge. J Am Coll Cardiol 2009; 54: 1561-75.

46. Wingo PA, Calle EE, McTiernan A. How does breast cancer mortality compare with that of other cancers and selected cardiovascular diseases at different ages in U.S. women? J Womens Health Gend Based Med 2000; 9: 999-1006.

47. Sakowicz A, Fendler W, Lelonek M, Pietrucha T. Genetic variability and the risk of myocardial infarction in Poles under 45 years of age. Arch Med Sci 2010; 6: 160-7.

48. Kolovou GD, Anagnostopoulou KK, Pavlidis AN, et al. Postprandial lipaemia in menopausal women with metabolic syndrome. Maturitas 2006; 55: 19-26.

49. Kolovou GD, Anagnostopoulou KK, Salpea KD, et al. Postprandial lipemia in postmenopausal women with high fasting high-density lipoprotein cholesterol. Am J Med Sci 2006; 331: 10-6.

50. Kolovou GD, Bilianou HG. Influence of aging and menopause on lipids and lipoproteins in women. Angiology 2008; 59: 54S-7S.

51. Bręborowicz P, Mularek-Kubzdela T, Oko-Sarnowska Z, et al. The effect of hormone replacement therapy on the left ventricle systolic and diastolic function in postmenopausal women with coronary artery disease. Arch Med Sci 2005; 1: $18-22$.

52. Beral V. Breast cancer and hormone-replacement therapy in the Million Women Study. Lancet 2003; 362: 419-27.

53. Miller VM, Black DM, Brinton EA, et al. Using basic science to design a clinical trial: baseline characteristics of women enrolled in the Kronos Early Estrogen Prevention Study (KEEPS). J Cardiovasc Transl Res 2009; 2: 228-39.

54. Shakir YA, Samsioe G, Nyberg P, Lidfeldt J, Nerbrand C. Cardiovascular risk factors in middle-aged women and the association with use of hormone therapy: results from a population-based study of Swedish women. The Women's Health in the Lund Area (WHILA) Study. Climacteric 2004; 7: 274-83.

55. Menon DV, Vongpatanasin W. Effects of transdermal estrogen replacement therapy on cardiovascular risk factors. Treat Endocrinol 2006; 5: 37-51

56. Lewandowski KC, Komorowski J, Mikhalidis DP, et al. Effects of hormone replacement therapy type and route of administration on plasma matrix metalloproteinases and their tissue inhibitors in postmenopausal women. J Clin Endocrinol Metab 2006; 91: 3123-30. 